\title{
PRODUCTION VIABILITY OF PASSION FRUIT AT HIGH PLANTING DENSITY IN JEQUITINHONHA VALLEY, MINAS GERAIS, BRAZIL
}

\author{
VIABILIDADE PRODUTIVA DE MARACUJAZEIRO-AMARELO COM \\ ADENSAMENTO DE PLANTIO NO VALE DO JEQUITINHONHA, MG
}

\begin{abstract}
Rodrigo Amato MOREIRA ${ }^{1}$; Maria do Céu Monteiro da CRUZ² ${ }^{2}$ Adriene de Matos SANTOS ${ }^{3}$; Denison Ramalho FERNANDES ${ }^{3}$; Jéssica de OLIVEIRA ${ }^{3}$

1. Professor, Doutor, Instituto Federal do Norte de Minas - IFNMG, Januária, MG, Brasil. amatomoreira@ yahoo.com.br; 2. Professora, Doutora, Universidade Federal dos Vales do Jequitinhonha e Mucuri - UFVJM, Diamantina, MG, Brasil; 3. Mestrandos do Programa de Pós-Graduação em Produção Vegetal, Universidade Federal dos Vales do Jequitinhonha e Mucuri - UFVJM, Diamantina, MG, Brasil.
\end{abstract}

\begin{abstract}
Passion fruit has faced many problems in productivity, supply, prices and quality of the fruit as a result of the inadequate management of the orchards and the low application of existing technology. Increased planting density may promote an increase in productivity and thus provide better income to the producer. In this sense, this experiment was performed to study the increase of planting density on productivity and on the quality of yellow passion fruit in Jequitinhonha Valley, Minas Gerais, Brazil. The evaluated spacings between plants were 2.0, 3.0, 4.0, 5.0 and 6.0 $\mathrm{m}$. The spacing between the rows was three meters, which corresponded to 1,667, 1,111, 833, 667 and 556 plants ha $^{-1}$, respectively. Production per plant, productivity, juice yield per hectare, transverse and longitudinal diameter, peel thickness, soluble solids, titratable acidity, and the soluble solids /titratable acidity ratio of fruits were evaluated. Increasing the planting density to 1,667 plants per hectare promoted greater productivity. The densification did not affect the quality of the fruits.
\end{abstract}

KEYWORDS: Passiflora edulis Sims. Spacing. Management.

\section{INTRODUCTION}

In the region of Jequitinhonha Valley, Minas Gerais, Brazil, with the prohibition of mining, which was one activity developed over the years, the lack of jobs has become a serious social problem that affects the population. Thus, the development of fruit production in the region has become a new source of potential income for the families of producers.

Among fruit trees, yellow passion fruit has the potential of a rapid economic return with production distribution through most of the year and a high value of the fruit, which makes this crop an interesting alternative for family farming. Moreover, the level of employment is high, which can create strong social character. An orchard with one hectare of yellow passion fruit can generate three to four direct jobs and requires seven to eight people in the production chain (FERREIRA et al., 2003).

However, passion fruit is facing many problems regarding productivity, supply, prices and the quality of the fruit as a result of the inadequate management of the orchards and the low application of existing technology.

In this context, in order for producers to achieve better incomes, it is necessary to increase productivity without compromising the quality of the fruit because higher yields usually lead to greater profitability.
Thus, the densification of the crop can be a good alternative for overcoming the problems related to the cultivation of yellow passion fruit. Higher plant densities can promote higher productivity during the first harvests and enable increased profitability, even when producers have to reform the orchards every two years due to the occurrence of pests and diseases that cause depletion, lower production and the death of the plants (HAFLE et al., 2012; MELO JUNIOR et al., 2012; CAVICHIOLI et al., 2014).

In this sense, this research was conducted to evaluate the production of yellow passion fruit with reduced crop spacing in the soil and weather conditions of Valley of Jequitinhonha, Minas Gerais, Brazil.

\section{MATERIAL AND METHODS}

The experiment was conducted in Couto Magalhães de Minas, Minas Gerais, Brazil, located at $18^{\circ} 04^{\prime} 15^{\prime \prime}$ South latitude and $43^{\circ} 28^{\prime} 15^{\prime \prime}$ 'West longitude at 726 meters of altitude. The soil was a dystrophic Yellow Latosol, with $60 \%$ sand, $27 \%$ clay and $13 \%$ silt. The climate is tropical with welldefined dry and rainy seasons. The variations in temperature and rainfall were recorded during the experimental period (Figure 1). 


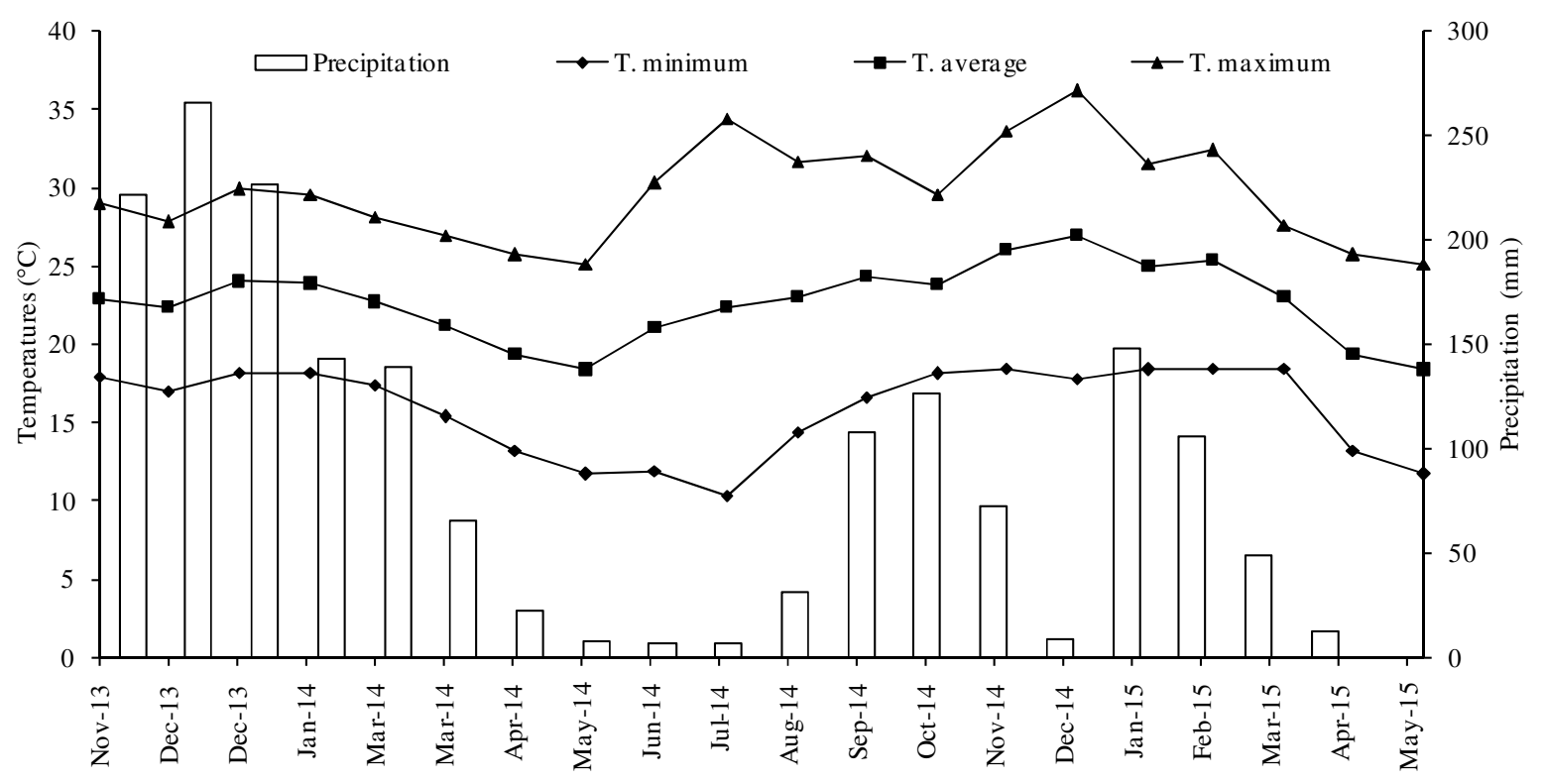

Figure 1. Average monthly temperatures [minimum (T. minimum), average (T. average) and maximum ( $\mathrm{T}$. maximum)] and monthly precipitation during the cultivation of yellow passion fruit, Couto Magalhães de Minas, Minas Gerais, Brazil.

Seedlings of yellow passion fruit (Passiflora edulis Sims) were produced from September to November 2013. The seeds were from ripe fruits acquired at the Diamantina market, Minas Gerais, Brazil by selecting fruit with characteristics desirable for the fruit fresh market; they were sown in plastic tubes with $120 \mathrm{~cm}^{3}$ volume, which were filled with commercial substrate Bioplant ${ }^{\circledR}$ and kept in greenhouse.
Fertilization and the correction of the planting holes were performed according to soil analyses (Table 1) and the recommendations for yellow passion fruit crop; an application of $200 \mathrm{~g}$ dolomitic limestone, $20 \mathrm{~L}$ cattle manure, $500 \mathrm{~g}$ superphosphate $\left(\mathrm{P}_{2} \mathrm{O}_{5}=18 \%, \mathrm{~S}=8 \%\right)$ and $50 \mathrm{~g} \mathrm{FTE}$ BR $12^{\circledR}(\mathrm{Ca}=7.1 \% ; \mathrm{S}=5.7 \%, \mathrm{~B}=1.8 \% ; \mathrm{Cu}=$ $0.8 \%, \mathrm{Mn}=2.0 \%, \mathrm{Mo}=0.1 \% ; \mathrm{Zn}=9.0 \%)$ was applied per hole 60 days before planting.

Table 1. Soil chemical analysis of the experimental area at the depths of 0 to $0.2 \mathrm{~m}$ and 0.2 to $0.4 \mathrm{~m}$ before planting in Couto Magalhães de Minas, Minas Gerais, Brazil.

\begin{tabular}{llllllll}
\hline \multirow{2}{*}{ Depth $(\mathrm{m})$} & $\mathrm{pH}$ & $\mathrm{P}$ & $\mathrm{K}$ & $\mathrm{Ca}$ & $\mathrm{Mg}$ & $\mathrm{Al}^{3+}$ & $\mathrm{H}+\mathrm{Al}$ \\
\cline { 2 - 8 } & $\mathrm{H}_{2} \mathrm{O}$ & $-----\mathrm{mg} \mathrm{dm}^{-3}------$ & $-------------\mathrm{cmol}_{\mathrm{c}} \mathrm{dm}^{-3}-------------$ \\
\hline $0-0.2$ & 5.10 & 1.83 & 40.70 & 1.00 & 0.30 & 0.50 & 3.70 \\
$0.2-0.4$ & 4.90 & 5.09 & 40.70 & 0.60 & 0.30 & 0.68 & 4.20 \\
\hline \multirow{2}{*}{ Depth (m) } & $\mathrm{SB}$ & $\mathrm{t}$ & $\mathrm{T}$ & $\mathrm{V}$ & $\mathrm{m}$ & $\mathrm{OM}$ & \\
\cline { 2 - 8 } & $------------\mathrm{cmol}_{\mathrm{c}} \mathrm{dm}^{-3}--------$ & $--------\%---------$ & $-----\mathrm{dag} \mathrm{dm}^{-3}-----$ \\
\hline $0-0.2$ & 1.40 & 1.90 & 5.10 & 28.00 & 26.00 & 0.40 & \\
$0.2-0.4$ & 1.00 & 1.70 & 5.20 & 19.00 & 40.00 & 0.10 & \\
\hline
\end{tabular}

pH: Soil-water relation 1:2.5; P and K: Mehlich-1 extractor; $\mathrm{Ca}, \mathrm{Mg}$ and $\mathrm{Al}$ : $\mathrm{KCl} 1 \mathrm{~mol} \mathrm{~L}^{-1}$ extractor; t: Cation exchange capacity; T: Cation exchange capacity at $\mathrm{pH}$ 7.0; m: Aluminum saturation; V: Base saturation; OM: Organic matter, determined by multiplying the results of organic carbon using the Walkey-Black method by 1.724 .

Planting was carried out during the rainy season in November 2013; seedlings $0.25 \mathrm{~m}$ tall were selected after the issuance of the first tendril. At the time of planting, one string of wire was tied at the base of the plants, and a wire trellis for tendril promotion was used to train the plants to the support system.
The plants were trained to an espalier vertical system. A wire was stretched horizontally at $1.8 \mathrm{~m}$ above the soil, and a primary branch led to the wire, and two secondary branches were trained to the wire; tertiary branches (productive ones) with pending growth were pruned to $0.2 \mathrm{~m}$ above the soil. 
The experimental design was in randomized blocks, with four blocks and three plants per plot. The spacing between evaluated plants were as follows: 2.0, 3.0, 4.0, 5.0, and $6.0 \mathrm{~m}$. The spacing between the rows was three meters, which corresponded to $1,667,1,111,833,667$ and 556 plants $\mathrm{ha}^{-1}$.

Fertilizer for plant growth was applied per planting hole at $70 \mathrm{~g} \mathrm{~N}$ and $90 \mathrm{~g} \mathrm{~K}_{2} \mathrm{O}$. Fertilization was divided into three applications at 30,60 and 120 days after transplanting the seedlings.

Fertilizer for production (first year postplanting) was applied per hole at $120 \mathrm{~g} \mathrm{~N}$ and $160 \mathrm{~g}$ $\mathrm{K}_{2} \mathrm{O}$ and was divided into three applications in November, January and March (2014/2015). In all fertilizations, the sources of $\mathrm{N}$ and $\mathrm{K}$ were ammonium sulfate and potassium chloride.

Weed management was conducted by hoeing the rows to prevent competition for water, light and nutrients and by mowing between the lines and keeping the straw to prevent exposure of the soil. Water for the plants was supplied using drip irrigation during periods of drought. Evaluations were conducted during the two production cycles when the fruits were harvested at the appropriate maturation stage.

The first harvest, called the off-season by some producers, is the first production and occurs in the off-season when the plants are not yet fully formed; the evaluations were performed from April to July 2014.

The second harvest is the production of plants that occurs when the plants have completed their development, usually about one year after planting; evaluations were performed from November 2014 to June 2015.

The production per plant was determined by taking direct weigh measurements of fruits per experimental plot. From the production data $(\mathrm{kg}$ per plant), productivity was determined for each planting density $\left(\mathrm{t} \mathrm{ha}^{-1}\right)$.

To determine juice yield, representative samples (10 fruits) for each spacing were taken for juice extraction. The fruits were weighed and pulped. The pulp was sieved to separate seed and the extracted juice volume. Individual juice yield was obtained by the ratio of extracted juice volume to its mass; the total juice yield of each treatment was calculated $\left(\mathrm{t} \mathrm{ha}^{-1}\right)$.

In the quality assessment, samples of 10 fruits per plot were separated, having $50 \%$ yellow skin coloration, to determine the mass (g), transverse and longitudinal diameters $(\mathrm{mm})$ peel thickness $(\mathrm{mm})$, soluble solids $\left({ }^{\circ} \mathrm{Bx}\right)$, titratable acidity (\% of citric acid) and the soluble solids / titratable acidity ratio.

The data were submitted to an analysis of variance and polynomial regression. The choice of model was based on the potential to explain the biological phenomenon in question, the coefficient of determination and the significance of the regression coefficients using the $\mathrm{t}$-test $(\mathrm{p}<0.05)$.

\section{RESULTS AND DISCUSSSION}

Differences were observed among the different spacings for the production per plant, productivity and juice yield in the two harvests. However, fruit quality was not affected by spacing.

The production per plant in the first harvest was $47.2 \%$ higher with the spacing of $4.5 \mathrm{~m}$ compared to plants spaced at $2.0 \mathrm{~m}$ (Figure 2A). In the second harvest, the response showed a linear increase, with higher production per plant at a spacing of $6.0 \mathrm{~m}$ (Figure 2B). The difference in production per plant between the first and second harvest occurred due to the conformation of the plants. In the first harvest, the plants at 5.0 and 6.0 $\mathrm{m}$ spacing were not fully developed, i.e., the secondary and tertiary branches (productive branches) were still developing. With the growth of new branches, assimilates were directed towards vegetative growth instead of production.

On the other hand, the lower production per plant with spacings of 2.0 and $3.0 \mathrm{~m}$ was due to the smaller area occupied by these plants; these plants had a smaller number of branches, which resulted in a reduction in the number of flowering buds and a lower number of fruits per plant (HAFLE et al., 2009).

In the second harvest, the largest number of fruits plants cultivated at $6.0 \mathrm{~m}$; this may be attributed to the greater number of productive branches due to the length of the secondary branches, which provided a greater production area.

The increase of production in plants cultivated at greater spacings is in accordance with Andrade Júnior et al. (2003), Araújo Neto et al. (2005) and Cavichioli et al. (2014).

In addition to the number of branches, which was determined by the length of the secondary branches as a function of spacing, the productive potential of yellow passion fruit was influenced by the genetic material used. Freitas et al. (2011) recorded variations from 15 to 115 fruits (3 $7.7 \mathrm{~kg}$ ) per plant in the first harvest when they evaluated the agronomic performance of 38 accessions of passion fruit in Cruz das Almas, Bahia, Brazil. In this experiment, although the 
yellow passion fruit were purchased from the local market, the observed values of production per plant with the spacing of $4.5 \mathrm{~m}$ were superior to the best accessions evaluated by these authors.
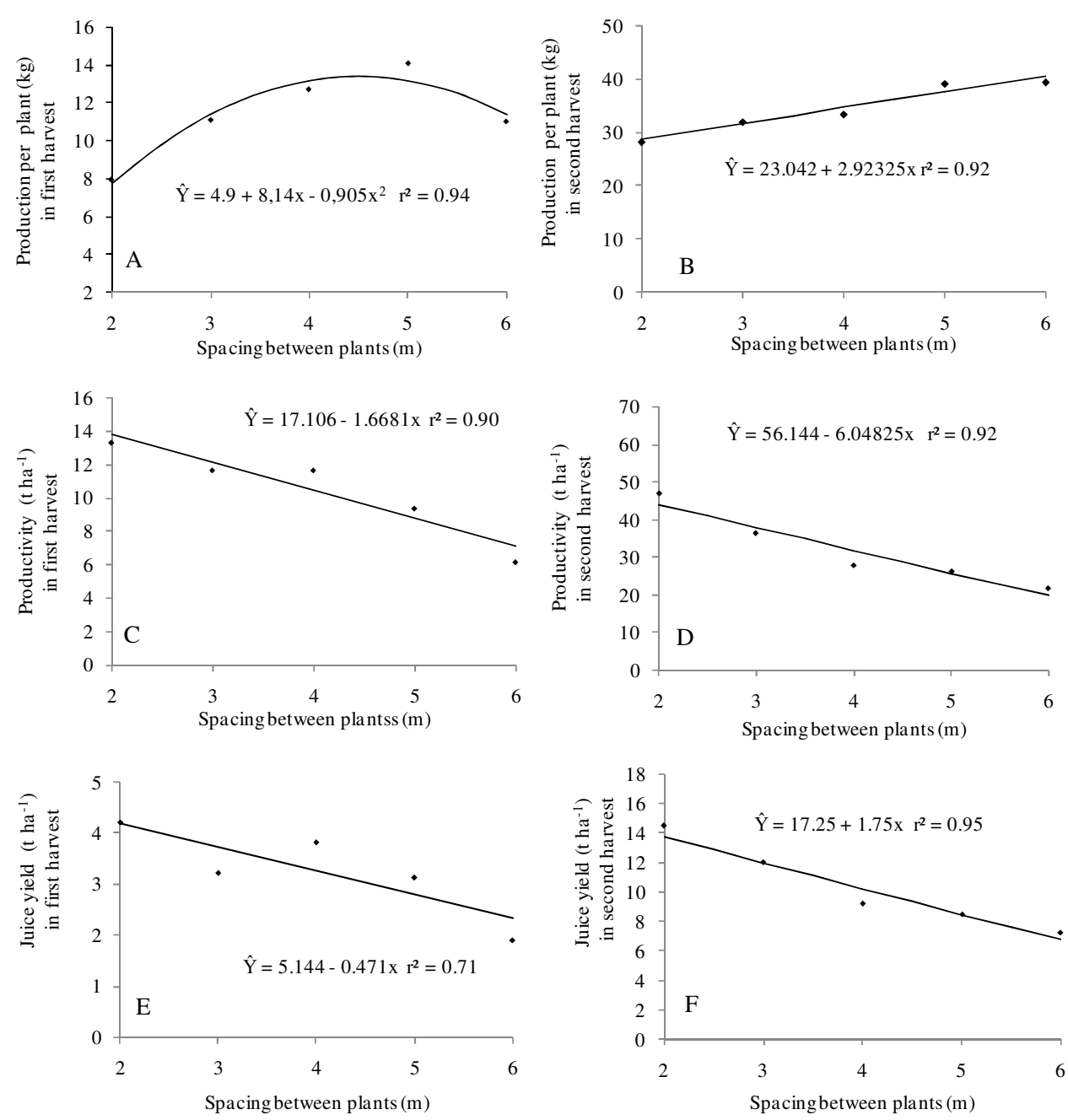

Figure 2. Production per plant (A) and (B), productivity $(C)$ and $(D)$, and juice yield (E) and (F) in first and second harvests of yellow passion fruit, respectively, cultivated at different planting spacings, Couto Magalhães de Minas, Minas Gerais, Brazil.

The highest productivity $13.7 \mathrm{t} \mathrm{ha}^{-1}$ was obtained with the highest density in the first harvest, which was $73.1 \%$ and $60.9 \%$ higher than the productivity of plants cultivated at spacings of 6.0 and $5.0 \mathrm{~m}$, respectively (Figure 2C); the highest productivity was $44.1 \mathrm{t} \mathrm{ha}^{-1}$ in the second harvest, which was $62.8 \%$ and $81.2 \%$ higher than plants spaced at $6.0 \mathrm{~m}$ and $5.0 \mathrm{~m}$ (Figure 2D).

The observed results are promising because in Minas Gerais, Brazil, the projection for the first harvest (off-season) and second harvest are $5.0 \mathrm{t} \mathrm{ha}^{-1}$ and $25.0 \mathrm{t} \mathrm{ha}^{-1}$, respectively, when the nutritional management used in this experiment was similar with the conventional spacing of $5.0 \mathrm{~m}$.

The observed values are also satisfactory when compared with studies performed in other regions with increased plant density. In Adamantina, São Paulo, Brazil, the productivity of yellow passion fruit at a density of 3,125 plants ha $^{-1}$ was $14.5 \mathrm{t} \mathrm{ha}^{-1}$, while at the density of 625 plants $\mathrm{ha}^{-1}$, the productivity was $4.3 \mathrm{t} \mathrm{ha}^{-1}$ in the first harvest (CHAVICHIOLLI et al., 2014). In São Tiago, Minas Gerais, Brazil, Araujo Neto et al. (2005) verified a productivity of $10.9 \mathrm{t} \mathrm{ha}^{-1}$ with a density of 1,841 plants ha ${ }^{-1}$.

For juice yield per hectare, in both harvests, the highest yield was observed at the spacing of 2.0 $\mathrm{m}$ and decreased with increased spacing (Figures 2E and $2 \mathrm{~F}$ ). In the first harvest, the plants cultivated at the spacing of $2.0 \mathrm{~m}$ had a juice yield $13.7 \mathrm{t} \mathrm{ha}^{-1}$ increase of $68.1 \%$, and in the second harvest, that increase was $55.92 \%$ compared to plants spaced at $6.0 \mathrm{~m}$. Juice yields are directly related to the productivities achieved in plants with these spacings. 
The results demonstrate that with the use of smaller spacing between plants, higher juice yield per hectare is obtained. In this sense, a producer in the Jequitinhonha Valley who has interest in producing yellow passion fruit destined for the industry or in processing these fruits in a family agribusiness can achieve higher profitability using the spacing of $2.0 \mathrm{~m}$ because it promotes higher juice yield.

Significant differences did not occur in mass, longitudinal and transverse diameters, peel thickness, soluble solids, titratable acidity and the soluble solids / titratable acidity ratio in the fruits cultivated at the different spacings in both harvests (Table 2). These results are important from the point of view of marketing, which enables the producer to adapt the best spacing without loss in the quality of the fruits.
The average fruit mass was $123.2 \mathrm{~g}$ in the first harvest and $127.5 \mathrm{~g}$ in the second harvest (Table 2). The fruits harvested can be classified as "extra A" (108-144 g), which is one median standard of classification according to the standardization carried out by the Quality Center for Horticulture in CEAGESP. The fruit size is one important feature, especially when the destination is the fresh fruit market, which prefer fruits of larger size.

The peel thickness varied from 4.55 to 5.43 $\mathrm{mm}$ and averaged at $4.86 \mathrm{~mm}$ (Table 2). The results presented are consistent with those observed by other authors (MELO JÚNIOR et al., 2012; AGUIAR et al., 2015), who reported peel thickness variations from 4.2 to $5.4 \mathrm{~mm}$ in yellow passion fruit.

Table 2. Mass (g), PT - peel thickness (mm), LD - longitudinal diameter (mm), and the TD - transverse diameter $(\mathrm{mm})$ of fruits in the first and second harvests of yellow passion fruit cultivated in the different planting spacings, Couto Magalhães de Minas, Minas Gerais, Brazil.

\begin{tabular}{|c|c|c|c|c|c|c|c|c|}
\hline \multirow{2}{*}{$\begin{array}{l}\text { Spacing } \\
\text { between plants } \\
\text { (m) }\end{array}$} & \multicolumn{2}{|l|}{ Mass } & \multicolumn{2}{|l|}{$\mathrm{PT}$} & $\mathrm{LD}$ & TD & $\mathrm{LD}$ & $\mathrm{TD}$ \\
\hline & $\begin{array}{l}1^{\text {st }} \\
\text { harvest }^{\text {ns }}\end{array}$ & $\begin{array}{l}2^{\text {nd }} \\
\text { harvest }^{\text {ns }}\end{array}$ & $\begin{array}{l}1^{\text {st }} \\
\text { harvest }^{\text {ns }}\end{array}$ & $\begin{array}{l}2^{\text {nd }} \\
\text { harvest }^{\text {ns }}\end{array}$ & $1^{\text {st }}$ harv & & $2^{\text {nd }}$ har & \\
\hline 2.0 & 120.70 & 127.40 & 5.52 & 4.55 & 84.04 & 71.75 & 81.08 & 67.79 \\
\hline 3.0 & 125.00 & 126.90 & 4.96 & 4.76 & 90.22 & 83.94 & 100.62 & 68.78 \\
\hline 4.0 & 122.10 & 123.40 & 4.60 & 4.96 & 81.87 & 75.99 & 82.04 & 67.22 \\
\hline 5.0 & 128.70 & 129.20 & 4.73 & 4.57 & 90.68 & 74.89 & 83.47 & 68.93 \\
\hline 6.0 & 119.70 & 130.80 & 4.56 & 5.32 & 93.32 & 77.03 & 82.21 & 68.04 \\
\hline Average & 123.20 & 127.50 & 4.87 & 4.85 & 88.03 & 72.72 & 85.88 & 68.16 \\
\hline CV (\%) & 19.40 & 7.40 & 10.50 & 12.80 & 6.20 & 5.30 & 12.00 & 3.50 \\
\hline
\end{tabular}

As shown by some authors, peel thickness values are inversely proportional to juice yield (NEGREIROS et al., 2007; VIANNA-SILVA et al., 2008). Thus, fruit with thinner peel, as observed in this study, have higher pulp yield, which is interesting for both for the fresh fruit market and for the industry.

Regarding the diameter of the fruits, means of 88.03 and $85.88 \mathrm{~mm}$ for the longitudinal diameter and 72.72 and $68.16 \mathrm{~mm}$ for the transverse diameter were observed in the first and second harvests, respectively (Table 2). The values observed in the fruits suggest a good price in the market because they are within the standard of "class 3A" $(\geq 65 \mathrm{~mm}$ and $<75 \mathrm{~mm}$ in transverse diameter), which is a good standard of classification by CEAGESP. Obtaining fruits with good classification guarantees the producer greater economic returns at the time of sale because at the fresh fruit market, size is one of the main parameters evaluated by consumers.

The sizes of fruits observed in this study were similar to fruit from other regions. In the Tangará da Serra, Mato Grosso, Brazil, the marketed fruits ranged from 69.5 to $78.6 \mathrm{~mm}$ in transvetsetransverse diameter and $73.3 \mathrm{~mm}$ to 94.1 $\mathrm{mm}$ in longitudinal diameter (TRENTIN et al., 2014).

The average of soluble solids was 14.55 and $14.72^{\circ} \mathrm{Bx}$ in the first and second harvests, respectively (Table 3 ). These results are consistent with that reported in the literature, which recorded variations from 11.65 to $17.29^{\circ} \mathrm{Bx}$ (ARAÚJO NETO et al., 2005; HAFLE et al., 2009; COBRA et al., 2015). 
Table 3. SS - Soluble solids $\left({ }^{\circ} \mathrm{Bx}\right)$, TA - titratable acidity $(\%)$ and the RT - soluble solids / titratable acidity ratio of the fruits in the first and second harvests of yellow passion fruit cultivated in different planting spacings, Couto Magalhães de Minas, Minas Gerais, Brazil.

\begin{tabular}{lllllll}
\hline \multirow{2}{*}{$\begin{array}{l}\text { Spacing between } \\
\text { plants (m) }\end{array}$} & \multicolumn{5}{c}{ TA } & \multicolumn{2}{c}{ RT } \\
\cline { 2 - 7 } & $\begin{array}{l}1^{\text {st }} \\
\text { harvest }^{\text {ns }}\end{array}$ & $\begin{array}{l}2^{\text {nd }} \\
\text { harvest }^{\text {ns }}\end{array}$ & $\begin{array}{l}1^{\text {st }} \\
\text { harvest }^{\text {ns }}\end{array}$ & $\begin{array}{l}2^{\text {nd }} \\
\text { harvest }^{\text {ns }}\end{array}$ & $\begin{array}{l}1^{\text {st }} \\
\text { harvest }^{\text {ns }}\end{array}$ & $\begin{array}{l}2^{\text {nd }} \\
\text { harvest }^{\text {ns }}\end{array}$ \\
\hline 2.0 & 15.05 & 14.78 & 4.23 & 2.92 & 3.59 & 5.13 \\
3.0 & 14.92 & 14.42 & 4.02 & 2.94 & 3.73 & 5.10 \\
4.0 & 13.78 & 14.80 & 4.49 & 3.18 & 3.10 & 4.76 \\
5.0 & 14.10 & 14.87 & 4.36 & 2.84 & 3.29 & 5.35 \\
6.0 & 14.80 & 14.71 & 4.23 & 2.97 & 3.59 & 4.95 \\
\hline Average & 14.55 & 14.72 & 4.26 & 2.97 & 3.46 & 5.06 \\
\hline CV $(\%)$ & 8.10 & 2.00 & 14.70 & 17.80 & 15.20 & 14.20 \\
\hline
\end{tabular}

ns - not significant $(\mathrm{p}<0.05)$

Fruits with high soluble solids are the most desirable for industrialization because approximately $11 \mathrm{~kg}$ of fruit are needed with soluble solids between $11 \%$ and $12 \%$ to obtain $1 \mathrm{~kg}$ of concentrated juice with $50^{\circ} \mathrm{Bx}$. Thus, the higher the total soluble, the lower the amount of pulp needed to obtain the product.

Regarding the titratable acidity, the values observed in both harvests (Table 3) are with the recommendation of 'Ministério da Agricultura e do Abastecimento', Brazil; as there is a minimum value of $2.5 \%$ for the titratable acidity in passion fruit juice for use in the industry, which enables the producer to market to both the fresh market and to the industry during the entire production period.

No variations in soluble solids and acidity favored the soluble solids /acidity ratio, which did not differ in the fruits from the different spacings; the average values were 3.46 in the first harvest and 5.06 in the second harvest (Table 3 ).

The variation from the first to second harvests in the soluble solids /acidity ratio can be attributed to the increase in the minimum temperature from $13.2{ }^{\circ} \mathrm{C}$ to $17.0{ }^{\circ} \mathrm{C}$ and in the maximum temperature from $25.7{ }^{\circ} \mathrm{C}$ to $27.8{ }^{\circ} \mathrm{C}$
(Figure 1), which may have influenced the decrease in acidity in the second harvest, as observed by Cavichioli et al. (2008).

According to the obtained results, the increase in planting density promoted the increase in the productivity of yellow passion fruit from the first harvest without reducing the quality of fruits. This result is very relevant because it enables producers to receive greater economic returns, which allow for the capitalization and the permanence of these producers in the activity.

\section{CONCLUSIONS}

Increasing the planting density to 1,667 plants per hectare promoted greater productivity. of the fruits.

The densification did not affect the quality

\section{ACKNOWLEDGEMENTS}

The authors wish to thank the Foundations for Supporting Research in the states of Minas Gerais (FAPEMIG) for financial support.

RESUMO: O maracujazeiro vem enfrentando muitos problemas com relação à produtividade, oferta, preços e qualidade da fruta, em consequência do manejo inadequado dos pomares, com a aplicação de baixa tecnologia existente. $\mathrm{O}$ aumento da densidade de plantio pode promover aumento da produtividade e assim proporcionar melhor renda ao produtor. Neste sentido, o trabalho foi desenvolvido com o objetivo de estudar o aumento da densidade de plantio na produtividade e na qualidade de frutos de maracujazeiro-amarelo nas condições edafoclimáticas do Alto Vale do Jequitinhonha, MG. Os espaçamentos utilizados entre plantas foram de 2,0; 3,0; 4,0; 5,0 e 6,0 m. O espaçamento entre linhas foi de três metros, o que correspondeu a 1.667; 1.111; 833; 667 e 556 plantas ha $^{-1}$. Foram avaliados: produção por planta, produtividade, rendimento de suco por hectare, diâmetros transversal e longitudinal, espessura de casca, sólidos solúveis, acidez titulável e ratio dos frutos. O aumento da densidade de plantio em 1.6667 plantas por hectare promove incremento da produtividade do maracujazeiro-amarelo. $\mathrm{O}$ adensamento não afeta a qualidade dos frutos.

PALAVRAS-CHAVE: Passiflora edulis Sims. Espaçamento. Manejo. 


\section{REFERENCES}

AGUIAR, R. S.; ZACCHEO, P. V. C.; STENZEL, N. M. C.; SERA, T.; NEVES, C. S. V. J. Produção e qualidade de frutos híbridos de maracujazeiro-amarelo no norte do Paraná. Revista Brasileira de Fruticultura, v. 37, n. 1, p. 130-137, mar. 2015. http://dx.doi.org/10.1590/0100-2945-012/14

ANDRADE JUNIOR, V. C.; ARAÚJO NETO, S. E.; RUFINI, J. C. M.; RAMOS, J. D. Produção de maracujazeiro-amarelo sob diferentes densidades de plantio. Pesquisa Agropecuária Brasileira, v. 38, n. 12, p.1381-1386, 2003. http://dx.doi.org/10.1590/S0100-204X2003001200004

ARAÚJO NETO, S. E.; RAMOS, J. D.; ANDRADE JÚNIOR, V. C.; RUFINI, J. C. M.; MENDONÇA, V.; OLIVEIRA, T. K. Adensamento, desbaste e análise econômica na produção do maracujazeiro-amarelo. Revista Brasileira de Fruticultura, v. 27, n. 3, p. 394-398, dez. 2005 http://dx.doi.org/10.1590/S010029452005000300014

CAVICHIOLI, J. C.; RUGGIERO, C.; VOLPE, C. A. Caracterização físico-química de frutos de maracujazeiro-amarelo submetidos à iluminação artificial, irrigação e ao sombreamento. Revista Brasileira de Fruticultura, v. 30, n. 3, p.649-656, set. 2008. http://dx.doi.org/10.1590/S0100-29452008000300015

CAVICHIOLI, J. C., KASAI, F. S., NASSER, M. D. Produtividade e características físicas de frutos de Passiflora edulis enxertado sobre Passiflora gibertii em diferentes espaçamentos de plantio. Revista Brasileira de Fruticultura, v. 36, n. 1, p.243-247, jan. 2014. http://dx.doi.org/10.1590/0100-2945-238/13

COBRA, S. S. O.; SILVA, C. A.; KRAUSE, W.; DIAS, D.C.; KARSBURG, I. V.; MIRANDA, A. F. Características florais e polinizadores na qualidade de frutos de cultivares de maracujazeiro azedo. Pesquisa Agropecuária Brasileira, v. 50, n. 1, p. 54-62, jan. 2015. http://dx.doi.org/10.1590/S0100204X2015000100006

FERREIRA, V. R.; SOUZA, P. M.; PONCIANO, N. J. A fruticultura como alternativa para a produção familiar no âmbito do PRONAF nos municípios de Campos dos Goytacazes e São Francisco do Itabopoana - RJ.

Revista Brasileira de Fruticultura, v. 25, n. 3, p.436-439, dez. 2003. http://dx.doi.org/10.1590/S010029452003000300019

FREITAS, J. P. X.; OLIVEIRA, E. J.; CRUZ NETO, A. J.; SANTO S, L. R. Avaliação de recursos genéticos de maracujazeiro-amarelo. Pesquisa Agropecuária Brasileira, v. 46, n. 9, p. 1013-1020, set. 2011. http://dx.doi.org/10.1590/S0100-204X2011000900007

HAFLE, O. M.; RAMOS, J. D.; MENDONÇA, V.; RUFINI, J. C. M.; SANTOS, V. M. Rendimento do pomar de maracujazeiro-amarelo após diferentes manejos de podas de renovação. Agrária, v. 7, n. 2, p.280-285, mar.jun. 2012. http://dx.doi.org/10.5039/agraria.v7i2a1673

MELO JÚNIOR, H. B.; ALVES, P. R. B.; MELO, B.; DUARTE, I. N.; TEIXEIRA L. M. Produção do maracujazeiro-amarelo sob diferentes sistemas de condução. Enciclopédia Biosfera, v. 8, n. 15, p.1412-1422, 2012.

NEGREIROS, J. R. S.; ÁLVARES, V.S.; BRUCKNER, C. H.; MORGADO, M. A. D.; CRUZ, C. D. Relação entre características físicas e o rendimento de polpa de maracujá-amarelo. Revista Brasileira de Fruticultura, v. 29, n. 3, p.546-549, dez. 2007. http://dx.doi.org/10.1590/S0100-29452007000300026

TRENTIN, J. P. R.; DALBOSCO, E. Z.; ALBUQUERQUE, A. N.; KRAUSE, D. P.; KRAUSE, W. Qualidade de frutos de maracujá azedo comercializados em Tangará da Serra-MT. Enciclopédia Biosfera, v.10, n. 19, p.1580-1586, 2014.

VIANNA-SILVA, T.; RESENDE, E. D.; PEREIRA, S. M. F.; VIANA, A.P.; ROSA, R. C. C.; CARLOS, L. A.; VITORAZI, L. Influência dos estádios de maturação sobre as características físicas dos frutos de maracujáamarelo. Bragantia, v. 67, n. 2, p. 521-525, 2008. http://dx.doi.org/10.1590/S0006-87052008000200029 